\title{
Distribution of PAHs and the PAH-degrading bacteria in the deep-sea sediments of the high-latitude Arctic Ocean
}

\author{
C. Dong ${ }^{1, *}$, X. Bai ${ }^{1,4, *}$, H. Sheng ${ }^{2}$, L. Jiao ${ }^{3}$, H. Zhou ${ }^{2}$, and Z. Shao ${ }^{1}$ \\ ${ }^{1}$ State Key Laboratory Breeding Base of Marine Genetic Resources; Key Laboratory of Marine Genetic Resources, Third \\ Institute of Oceanography, SOA; Key Laboratory of Marine Genetic Resources of Fujian Province, \\ Xiamen 361005, Fujian, China \\ ${ }^{2}$ Department of Environmental Health, School of Public Health and Tropical Medicine, Southern Medical University, \\ Guangzhou, 510515, Guangdong, China \\ ${ }^{3}$ Key Laboratory of Global Change and Marine-Atmospheric Chemistry, the Third Institute of Oceanography, \\ State Oceanic Administration, Xiamen, 361005, Fujian, China \\ ${ }^{4}$ Life Science College, Xiamen University, Xiamen, 361005, Fujian, China \\ *These authors contributed equally to this work.
}

Correspondence to: Z. Shao (shaozz@163.com)

Received: 24 August 2014 - Published in Biogeosciences Discuss.: 29 September 2014

Revised: 1 February 2015 - Accepted: 20 March 2015 - Published: 13 April 2015

\begin{abstract}
Polycyclic aromatic hydrocarbons (PAHs) are common organic pollutants that can be transferred long distances and tend to accumulate in marine sediments. However, less is known regarding the distribution of PAHs and their natural bioattenuation in the open sea, especially the Arctic Ocean. In this report, sediment samples were collected at four sites from the Chukchi Plateau to the Makarov Basin in the summer of 2010. PAH compositions and total concentrations were examined with GC-MS. The concentrations of 16 EPA-priority PAHs varied from 2.0 to $41.6 \mathrm{ng} \mathrm{g}^{-1}$ dry weight and decreased with sediment depth and movement from the southern to the northern sites. Among the targeted PAHs, phenanthrene was relatively abundant in all sediments. The $16 \mathrm{~S}$ rRNA gene of the total environmental DNA was analyzed with Illumina high-throughput sequencing (IHTS) to determine the diversity of bacteria involved in PAH degradation in situ. The potential degraders including Cycloclasticus, Pseudomonas, Halomonas, Pseudoalteromonas, Marinomonas, Bacillus, Dietzia, Colwellia, Acinetobacter, Alcanivorax, Salinisphaera and Shewanella, with Dietzia as the most abundant, occurred in all sediment samples. Meanwhile, enrichment with PAHs was initiated onboard and transferred to the laboratory for further enrichment and to obtain the degrading consortia. Most of the abovementioned bacteria in addition to Hahella, Oleispira,
\end{abstract}

Oceanobacter and Hyphomonas occurred alternately as predominant members in the enrichment cultures from different sediments based on IHTS and PCR-DGGE analysis. To reconfirm their role in $\mathrm{PAH}$ degradation, 40 different bacteria were isolated and characterized, among which Cycloclasticus and Pseudomonas showed the best degradation capability under low temperatures. Taken together, PAHs and PAH-degrading bacteria were widespread in the deepsea sediments of the Arctic Ocean. We propose that bacteria of Cycloclasticus, Pseudomonas, Pseudoalteromonas, Halomonas, Marinomonas and Dietzia may play the most important role in PAH mineralization in situ.

\section{Introduction}

The Arctic Ocean is the smallest major ocean and is almost completely surrounded by land. It also has the most extensive shelves of any ocean basin. The loading of terrigenous organic carbon via rivers flowing into the Arctic Ocean (Opsahl et al., 1999; Lobbes et al., 2000; Benner et al., 2004) and the influence of terrigenous organic matter on bacterial diversity in coastal waters have drawn attention (Ortega-Retuerta et al., 2012; Boeuf et al., 2014). 
Polycyclic aromatic hydrocarbons (PAHs) are a type of aromatic hydrocarbon with two or more fused benzene rings. PAHs tend to accumulate in marine sediments and are a source of significant environmental concern due to their toxicity, mutagenicity and carcinogenicity (Haritash and Kaushik, 2009). Because PAHs are one of the main components of crude oil (in addition to aliphatic hydrocarbons), the presence of PAHs in marine environments is mainly attributed to oil spills, discharge and natural seepage, river import, or even air current transfer (Latimer and Zheng, 2003). Therefore, the increase in human activities globally has increased the risks to marine environments.

The Arctic Ocean remains less exploited due to its remoteness and ice cover. However, worries concerning the Arctic ecosystem have increased in recent years. According to an assessment by the US Geological Survey, approximately 30 and $13 \%$ of the world's undiscovered gas and oil reserves, respectively, may be found in the Arctic region (Gautier et al., 2009). Oil-drilling platforms have been set up on some offshore shelves (McClintock, 2011; Schmidt, 2012). With the oil exploitation and the future opening of the northeast and northwest passages, the increased input of PAHs into this area is unavoidable.

PAHs are widespread in marine coastal sediments (Baumard et al., 1998; Witt, 1995). They have also been found in surface sediments of the Arctic Ocean, with variable concentrations from the shelf to basin (Yunker and Macdonald, 1995; Zaborska et al., 2011; Yunker et al., 2011). On the Beaufort Sea shelf, the total concentrations of PAHs with a molecular weight of $178-278$ reached $850 \pm 230 \mathrm{ng} \mathrm{g}^{-1}$ dry weight $(\mathrm{dw})$, with phenanthrene, benzo[ghi]perylene and benzo $[b+k]$ fluoranthene as the dominant constituents (Yunker and Macdonald, 1995). In the western Barents Sea, the values of $\Sigma$ PAHs ranged from 35 to $132 \mathrm{ng} \mathrm{g}^{-1} \mathrm{dw}$. Benzo $[b+k]$ fluoranthene and phenanthrene dominated in the southern and northern areas, respectively (Zaborska et al., 2011). In contrast, the total concentration of PAHs was much lower in the high-latitude deep-sea basins, such as the Makarov Basin (35 $\mathrm{ng} \mathrm{g}^{-1} \mathrm{dw}$ ) (Yunker et al., 2011).

As to the origin of PAHs in deep-sea sediments, longrange atmospheric transport and abiogenic production in deep-sea hydrothermal vents are believed to contribute to the accumulation of PAHs (Friedman and Selin, 2012; Proskurowski et al., 2008; Simoneit et al., 2004; Konn et al., 2009). In addition to the combustion particulates contributed by atmospheric transport, the Arctic Ocean also receives a large input of terrigenous and fossil particulate organic matters delivered by fluvial transport and coastal erosion (Yunker et al., 2011). For example, industry in the former Soviet Union provided a widespread source of atmospheric PAHs to the Canadian High Arctic, which substantially decreased in the 1990s (Halsall et al., 1997; Becker et al., 2006). Therefore, these allochthonous PAHs could serve as carbon sources for various PAH-degrading bacteria in the Arctic sediments.
It is well known that bacterial degradation plays an important role in PAH removal from marine environments. Many PAH-degrading bacteria have been found in coastal sediments, including bacteria of Cycloclasticus (Dyksterhouse et al., 1995), Marinobacter (Hedlund et al., 2001), Pseudoalteromonas (Melcher et al., 2002), Marinomonas (Melcher et al., 2002), Halomonas (Melcher et al., 2002), Sphingomonas (Demaneche et al., 2004) and Vibrio (Hedlund and Staley, 2001). However, less is known regarding deep-sea environments. In previous studies on the deep-sea sediments of the Atlantic Ocean and Pacific Ocean, we found that Cycloclasticus was the most important bacterium, in addition to Alteromonas and Novosphingobium (Cui et al., 2008; Shao et al., 2010; Wang et al., 2008). In the Arctic Ocean, Pseudoalteromonas, Pseudomonas, Psychrobacter, Marinobacter and Shewanella have been frequently reported as crude oil degraders in coastal seawater and sea ice (Deppe et al., 2005; Gerdes et al., 2005; Brakstad and Bonaunet, 2006; Giudice et al., 2010). Pseudomonas was found to be the predominant PAH degrader in terrestrial soils (Whyte et al., 1997; Sorensen et al., 2010; Eriksson et al., 2003). To the best of our knowledge, the diversity of PAH-degrading bacteria remains unknown in the deep-sea sediments of the highlatitude Arctic Ocean.

During the ecological survey of the Xuelong icebreaker in 2010, we sampled deep-sea sediments across the ocean and chose four sites at the Chukchi Plateau, Canada Basin, Alpha Ridge and Makarov Basin to examine the distribution of PAHs and PAH-degrading bacteria therein. Bacterial diversity in both sediments and PAH enrichment cultures was analyzed. The role of bacteria involved in PAH degradation was evaluated. The results will contribute to the depiction of the distribution pattern of PAHs and PAH-utilizing bacteria in this extreme environment, and help to evaluate the fate of PAHs following the contamination of such environments.

\section{Material and methods}

\subsection{Sediment collection}

A total of 19 sediment cores were collected from the Chukchi Plateau, Canada Basin, Alpha Ridge and Makarov Basin during the fourth Arctic Research Expedition of the Xuelong icebreaker in the summer of 2010. PAHs and PAH-degrading bacteria are supposed to be varied in the regions with large distances. Based on this hypothesis, four sites representing the four typical geographical regions were chosen, i.e., sites BN03, BN06, BN09 and BN12 (Fig. 1, Table S1 in the Supplement). The sediment cores were first sampled using a box sampler $(50 \times 50 \times 65 \mathrm{~cm})$, then subsampled using a push core sampler $(\Phi 10 \times 60 \mathrm{~cm})$ prior to releasing the box corers on deck. The length of the BN03, BN06, BN09 and BN12 cores was $20,30,24$ and $38 \mathrm{~cm}$ below the surface, respectively. Subsequently, the cores were sliced into layers 


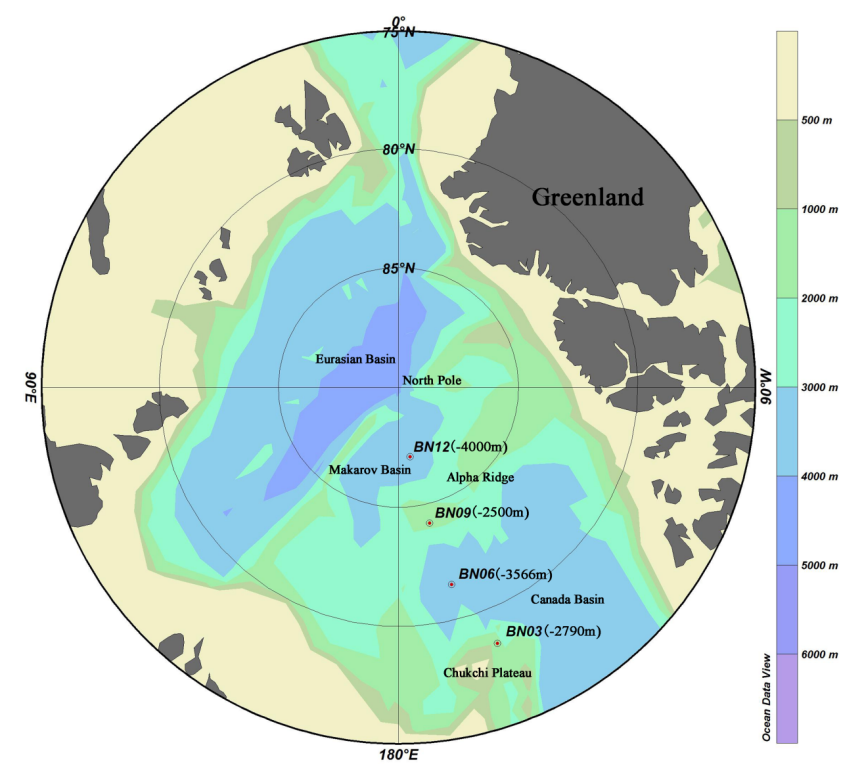

Figure 1. Locations of the deep-sea sediment sampling sites in the high-latitude Arctic Ocean.

at depth intervals of $4 \mathrm{~cm}$ with the exception of the surface layer, which was sliced at a depth of 2 or $4 \mathrm{~cm}$ depending on the water content. Finally, three layers from each core, i.e., the surface, the bottom and the middle (Table S1), were selected for analysis in this report. Approximately $5 \mathrm{~g}$ of sediment from each selected layer was used for PAH enrichment onboard. The remains of the sediments were frozen immediately at $-20^{\circ} \mathrm{C}$ onboard, transported to the home laboratory on dry ice, and stored at $-80^{\circ} \mathrm{C}$ until further analyses of PAH content and microbial diversity.

\subsection{Chemicals and media}

Naphthalene (>99.8\%) was purchased from Sinopharm Chemical Reagent (Shanghai, China), and phenanthrene (>97\%) and pyrene (>98\%) were purchased from SigmaAldrich (St. Louis, USA). The 16 EPA priority pollutant PAH standards, 6 types of surrogate standards (1,4dichlorobenzene-d4, naphthalene-d8, acenaphthene-d10, chrysene-d12, phenanthrene-d10 and perylene-d12) and an internal standard ( $m$-terphenyl) were purchased from AccuStandard (New Haven, USA). Surrogate and internal standards were used for quantifying procedural recovery and target PAH quantification, respectively. Crude oil was obtained from Iraq and imported by the SinoChem Quanzhou Petrochemical Corporation (Quanzhou, China). Mineral medium, used for enrichment of $\mathrm{PAH}$-degrading bacteria, contained $1 \mathrm{~g}$ of $\mathrm{NH}_{4} \mathrm{NO}_{3}, 0.8 \mathrm{~g}$ of $\mathrm{KH}_{2} \mathrm{PO}_{4}, 0.2 \mathrm{~g}$ of $\mathrm{K}_{2} \mathrm{HPO}_{4}, 2.8 \mathrm{mg}$ of $\mathrm{FeSO}_{4}$ and $1 \mathrm{~L}$ of in situ deep-sea water from the Arctic Ocean. ONR7a medium, used for the cultivation of bacteria from the enriched cultures, contained $22.8 \mathrm{~g}$ of $\mathrm{NaCl}, 11.2 \mathrm{~g}$ of $\mathrm{MgCl}_{2} \times 6 \mathrm{H}_{2} \mathrm{O}, 3.9 \mathrm{~g}$ of
$\mathrm{Na}_{2} \mathrm{SO}_{4}, 1.5 \mathrm{~g}$ of $\mathrm{CaCl}_{2} \times 2 \mathrm{H}_{2} \mathrm{O}, 1.3 \mathrm{~g}$ of TAPSO, $0.7 \mathrm{~g}$ of $\mathrm{KCl}, 0.3 \mathrm{~g}$ of $\mathrm{NH}_{4} \mathrm{Cl}, 89 \mathrm{mg}$ of $\mathrm{Na}_{2} \mathrm{HPO}_{4} \times 7 \mathrm{H}_{2} \mathrm{O}, 83 \mathrm{mg}$ of $\mathrm{NaBr}, 31 \mathrm{mg}$ of $\mathrm{NaHCO}_{3}, 27 \mathrm{mg}$ of $\mathrm{H}_{3} \mathrm{BO}_{3}, 24 \mathrm{mg}$ of $\mathrm{SrCl}_{2} \times 6 \mathrm{H}_{2} \mathrm{O}, 2.6 \mathrm{mg}$ of $\mathrm{NaF}, 2.0 \mathrm{mg}$ of $\mathrm{FeCl}_{2} \times 4 \mathrm{H}_{2} \mathrm{O}$ and $1 \mathrm{~L}$ of deionized water (Dyksterhouse et al., 1995).

\subsection{PAHs quantification of deep-sea sediments}

Extraction, purification and gas chromatography-mass spectrometry (GC-MS) quantification of the PAHs in the deep-sea sediment samples were performed according to EPA method 8270D-2007 and previous reports (Zheng et al., 2002), with some modifications. Briefly, $0.05 \mathrm{~mL}$ of the $1 \mathrm{mg} \mathrm{L}^{-1}$ surrogate standard mixture solution was spiked into $20 \mathrm{~g}$ of freezedried sediment prior to extraction. Then, the sediment was placed into a B-811 extraction system (Büchi) and extracted with $250 \mathrm{~mL}$ of solvent consisting of a mixture of $n$-hexane and dichloromethane $(1: 1 v / v)$ in hot extraction mode for $4 \mathrm{~h}$. The extract was concentrated using a vacuum rotary evaporator and cleaned using column chromatography. The cleaned-up extract was further concentrated to $1 \mathrm{~mL}$ under a gentle $\mathrm{N}_{2}$ stream. Finally, $0.05 \mathrm{~mL}$ of $1 \mathrm{mg} \mathrm{L}^{-1} m$-terphenyl was added to the extract as an internal standard immediately before analysis.

All of the samples were analyzed using GC-MS run in the selected ion monitoring (SIM) mode. The molecular ion of each PAH was used for SIM. Sixteen target PAHs were identified based on both retention time relative to known standards and the mass of the molecular ion. Five calibration standard solutions $\left(0.01-500 \mathrm{mg} \mathrm{L}^{-1}\right)$ containing the PAH standard, internal standard and surrogate compounds were carefully prepared, and a calibration curve was generated. The mean of the relative response factors (RRFs) for each target PAH and the surrogate compounds was calculated. The quantifications were performed using the internal standard method, and the concentrations of target PAHs were corrected for the recoveries. The recoveries for surrogate standards were 81.6-105.2\%. The lowest detection limit for each type of target PAH ranged from 0.13 to $0.97 \mathrm{ng} \mathrm{g}^{-1} \mathrm{dw}$.

\subsection{PAH-degrading bacteria enrichment}

Approximately $5 \mathrm{~g}$ of sediment from each selected layer was added to $250 \mathrm{~mL}$ of mineral medium in a $500 \mathrm{~mL}$ sterile polypropylene bottle. The sediments were supplied with $1 \mathrm{~mL}$ of crude oil spiked with a PAHs mixture of naphthalene, phenanthrene and pyrene at final concentrations of $0.02,0.01$ and $0.005 \mathrm{gL}^{-1}$, respectively. Enrichment was performed onboard at $4{ }^{\circ} \mathrm{C}$ and kept in the dark without agitation for 2 months. Only slight bacterial growth was observed after the first round of enrichment at $4{ }^{\circ} \mathrm{C}$. Once back to the home laboratory, the enriched cultures were transferred with an inoculum of $5 \%$ to $100 \mathrm{~mL}$ of fresh mineral medium in a $250 \mathrm{~mL}$ flask with the PAH mixture (without crude oil) as the sole carbon and energy source; this process was repeated 
twice in the rotary shakers $(150 \mathrm{rpm})$ at 25 and $15^{\circ} \mathrm{C} \mathrm{ev}$ ery 1 and 2 months, respectively. Finally, $36 \mathrm{PAH}$-degrading enriched cultures were obtained from the three temperature treatments.

\subsection{PAH-removal extent quantification by GC-MS}

To determine the PAH-removal extent of each consortium, all of the consortia and uninoculated controls were incubated in a $250 \mathrm{~mL}$ flask, which was loaded with $100 \mathrm{~mL}$ of fresh mineral medium containing $5 \%$ inoculum and the abovementioned PAH mixtures as the carbon source. After a 45day incubation at 15 and $25^{\circ} \mathrm{C}$, the residual PAHs were extracted with $100 \mathrm{~mL}$ of dichloromethane separated into three parts. The purification and concentration of these combined extracts was accomplished according to the description in Sect. 2.3. The residual PAHs were quantified using an external standard method. The recovery rate for each of PAH was calculated based on the quantity difference before and after enrichment, extraction and purification in the uninoculated controls. The PAH-removal extent was calculated according to the following formula:

Removal extent $(\%)=\frac{\mathrm{tPAH}-\left({ }^{\mathrm{PPH}} / R\right)}{\mathrm{tPAH}} \times 100 \%$,

where tPAH is total quantity of each type of PAH before enrichment, $\mathrm{PAH}$ is the residual quantity of each type of PAH after enrichment, and $R$ is the recovery rate of each type of PAH.

\subsection{Illumina high-throughput sequencing (IHTS) and data analysis}

Community DNA of three selected layers from each core and the enriched cultures was extracted using the PowerSoil DNA Isolation Kit (MoBio) according to the manufacturer's instructions. Amplification of the 16S rRNA gene V6 region was performed using the universal bacterial primers 967F (5'-CNACGCGAAGAACCTTANC-3') and 1046R (5'-CGACAGCCATGCANCACCT-3') as previously described (Wu et al., 2010). A set of 10 nucleotide (nt) barcodes was designed and added to the 5 , end of $967 \mathrm{~F}$ for multiplexing of the samples in the Solexa paired-end (PE) sequencing runs. Each $25 \mu \mathrm{L}$ PCR mixture consisted of approximately $10 \mathrm{ng}$ of community DNA, $0.2 \mu \mathrm{M}$ of each primer, $0.2 \mathrm{mM}$ of each dNTP, $1.5 \mathrm{mM} \mathrm{MgCl} 2,1 \times \mathrm{TaKaRa}_{2} \mathrm{Taq}$ buffer $\left(\mathrm{Mg}^{2+}\right.$-free) and 2.5 units of TaKaRa Ex Taq DNA polymerase. PCR amplification was conducted using the following thermocycles: initial denaturation at $94^{\circ} \mathrm{C}$ for $2 \mathrm{~min}$; 25 cycles at $94^{\circ} \mathrm{C}$ for $30 \mathrm{~s}, 57^{\circ} \mathrm{C}$ for $30 \mathrm{~s}$ and $72^{\circ} \mathrm{C}$ for $30 \mathrm{~s}$; and a final extension at $72{ }^{\circ} \mathrm{C}$ for $5 \mathrm{~min}$. Equimolar amplicon suspensions were combined and subjected to PE sequencing using the PE75 strategy on the Illumina HiSeq2000 sequencing platform at the Beijing Berry Genomics company.

\subsection{PCR-DGGE}

PCR amplification and DGGE analysis of the 16S rRNA gene V3 fragments of the enriched consortia were performed as previously reported (Cui et al., 2008).

\subsection{Bacterial isolation, identification and phylogenetic analysis}

Cultures enriched at $15^{\circ} \mathrm{C}$ were chosen as representatives for the isolation of degrading bacteria. Approximately $10^{-4}$, $10^{-5}$ and $10^{-6}$ dilutions of theses cultures were spread onto ONR7a agar plates whose lids were supplemented with naphthalene crystals and incubated at $15^{\circ} \mathrm{C}$ in the dark. Colonies with different morphologies were streaked onto fresh ONR7a plates twice to obtain pure cultures. The PAH utilization of these isolates was tested in $100 \mathrm{~mL}$ of ONR7a liquid medium supplemented with $0.2 \mathrm{~g}$ of ultraviolet-sterilized naphthalene crystals at $15^{\circ} \mathrm{C}$, reflected by culture color changes and an increase in the cell optical density at $600 \mathrm{~nm}$.

\subsection{Nucleotide sequence accession numbers}

The Illumina high-throughput sequencing data that resulted from the present study were deposited into the NCBI Sequence Read Archive under run accession numbers SRR975490-SRR975525 and SRR768499-SRR768507. The partial sequences of the 16S rRNA gene obtained in this study were deposited into GenBank under accession numbers KF470969-KF471008 (strains) and KC581800-KC581881 (DGGE bands).

\section{Results}

\subsection{PAHs in sediments}

GC-MS quantification indicated that the total concentration of the 16 targeted PAHs $\left(\Sigma_{16} \mathrm{PAH}\right)$ ranged from 2.02 to $41.63 \mathrm{ng} \mathrm{g}^{-1} \mathrm{dw}$ (Table S2) and was decreased in the sediments from the southern to northern sites (Fig. 2, Table S2). Among the sites, the southernmost site at Chukchi Plateau (BN03) ranked the highest, whereas the northernmost site at Makarov Basin (BN12) ranked the lowest. At each site, the $\Sigma_{16} \mathrm{PAH}$ decreased with sediment depth, with the exception of the site at the Chukchi Plateau (BN03). The concentration of phenanthrene ranked the highest among the detected PAHs, followed by naphthalene; the only exception was the sediments of the Chukchi Plateau (Fig. 2, Table S2). PAHs with four to six rings, such as the fourringed pyrene, five-ringed benzo[b]fluoranthene, and sixringed benzo[ghi]perylene and indenopyrene, were significantly higher at the Chukchi Plateau site (BN03) compared to the other samples. At the Alpha Ridge site (BN09), phenanthrene ranked the highest (14.61 $\mathrm{ng} \mathrm{g}^{-1} \mathrm{dw}$ ) among the PAHs of all samples. 


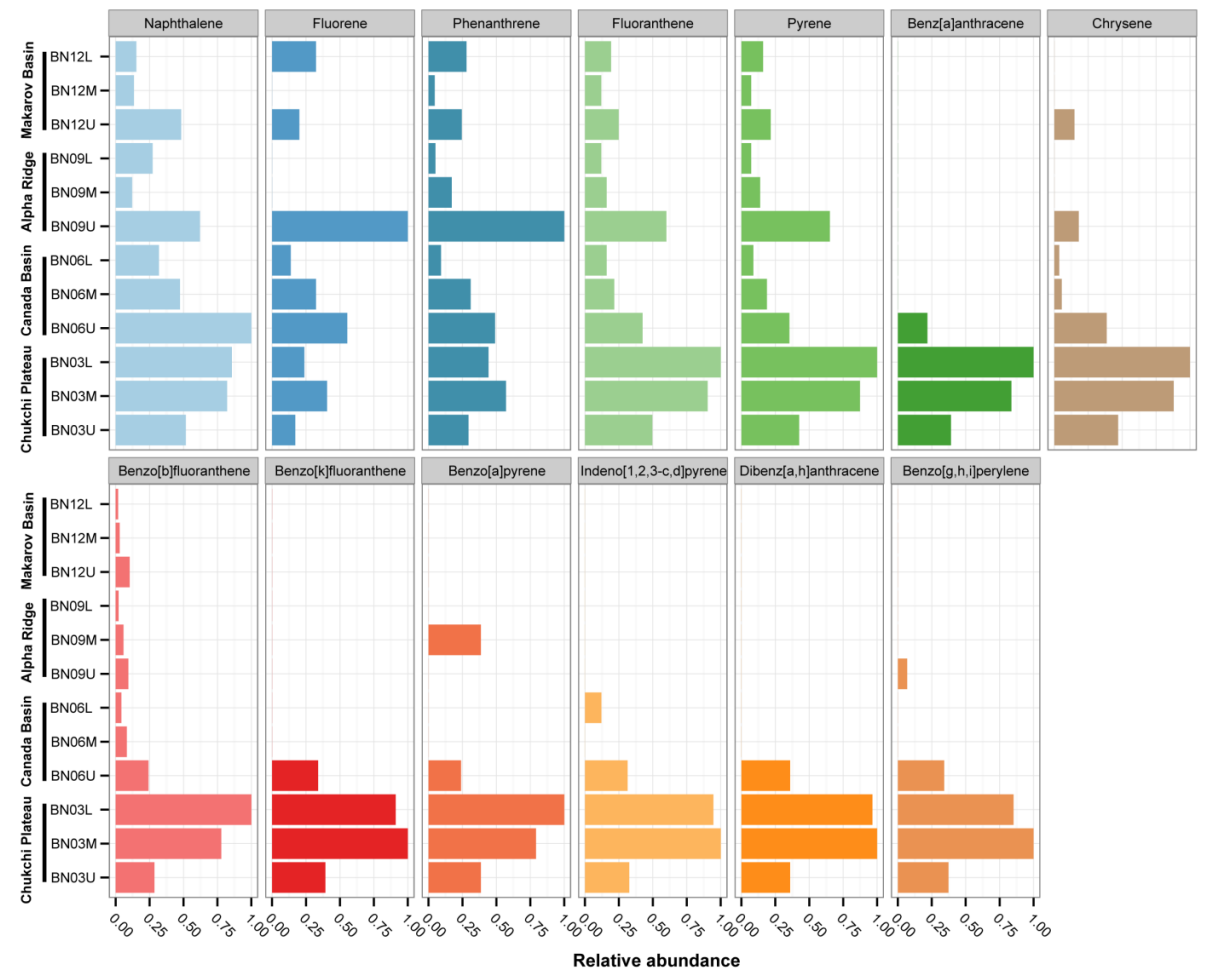

Figure 2. The distribution and relative abundance of 16 EPA-priority PAHs in the sediments of the Arctic Ocean. For each PAH, its relative abundance in all 12 samples was presented using different bar lengths in a sub-plot. The longest bar in a sub-plot indicates that this sample has the highest concentration value of a PAH in all 12 samples. The length of the other bars was proportionately shorted based on the ratios of the concentration values of other samples divided by the most abundant PAH in this sample. Acenaphthylene, acenaphthene and anthracene were not presented in this plot because their concentrations were below the detection limits in all sediment samples. U, M and L in the sample names refer to the upper, middle and lower layers of the sediments, respectively.

\subsection{Community structures of the in situ sediments revealed by IHTS}

To obtain the bacterial composition and increased insights into the PAH degraders present in the in situ sediments, all 12 samples were subjected to Illumina high-throughput sequencing. The sequencing efforts and bacterial diversity indices are presented in the Supplement in Table S3. Finally, a total of 1152388 raw reads were obtained, of which 1051978 clean reads were used for further analyses using QIIME (v 1.7.0).

At the phylum level, Proteobacteria were the most abundant bacteria and occupied $44.7-57.3 \%$ of the total tags of these sediments, followed by Acidobacteria, Actinobacteria, Gemmatimonadetes and Planctomycetes (Fig. S1A). The abundant orders are presented in the Supplement (Fig. S1B). The top 10 dominant bacteria belonged to Oceanospirillales, Actinomycetales, Rhodospirillales, Planctomycetales, Gemmatimonadales, Acidobacteriales, Chromatiales, Alteromonadales, Pseudomonadales and Bacillales. Among them, Oceanospirillales, Alteromonadales and Pseudomonadales contained most of the known oil and PAH-degrading bacteria by far, such as Pseudomonas, Cycloclasticus, Alcanivo- rax, Pseudoalteromonas and Marinomonas. More details are documented below.

The bacteria at the genus level are shown in Fig. 3a. The abundant bacteria that occupied more than $1 \%$ of the total tags in at least one sample are presented, including 20 known genera and 3 uncultured bacterial groups (Table S4). Among them, Dietzia, Salinisphaera, Pseudomonas, Acinetobacter, Pseudoalteromonas, Colwellia, Bacillus, Rhodovibrio, Marinomonas and Halomonas have been reported as hydrocarbon-degrading bacteria in marine environments. In addition, Cycloclasticus and Alcanivorax are noteworthy because they have been recognized as obligate marine hydrocarbon degraders (Yakimov et al., 2007), and they were widespread in all of the sediments tested in this report (Table S4). Specifically, Cycloclasticus occupied $0.2-0.5 \%$ of the 16S rRNA gene tags in each sample.

\subsection{PAH degradation of the PAH enrichment consortia}

All treatments displayed obvious bacterial growth following incubation under different temperatures $\left(4,15\right.$ and $\left.25^{\circ} \mathrm{C}\right)$, reflected by color changes and changes in the turbidity of the cultures compared to the uninoculated controls. The PAH- 

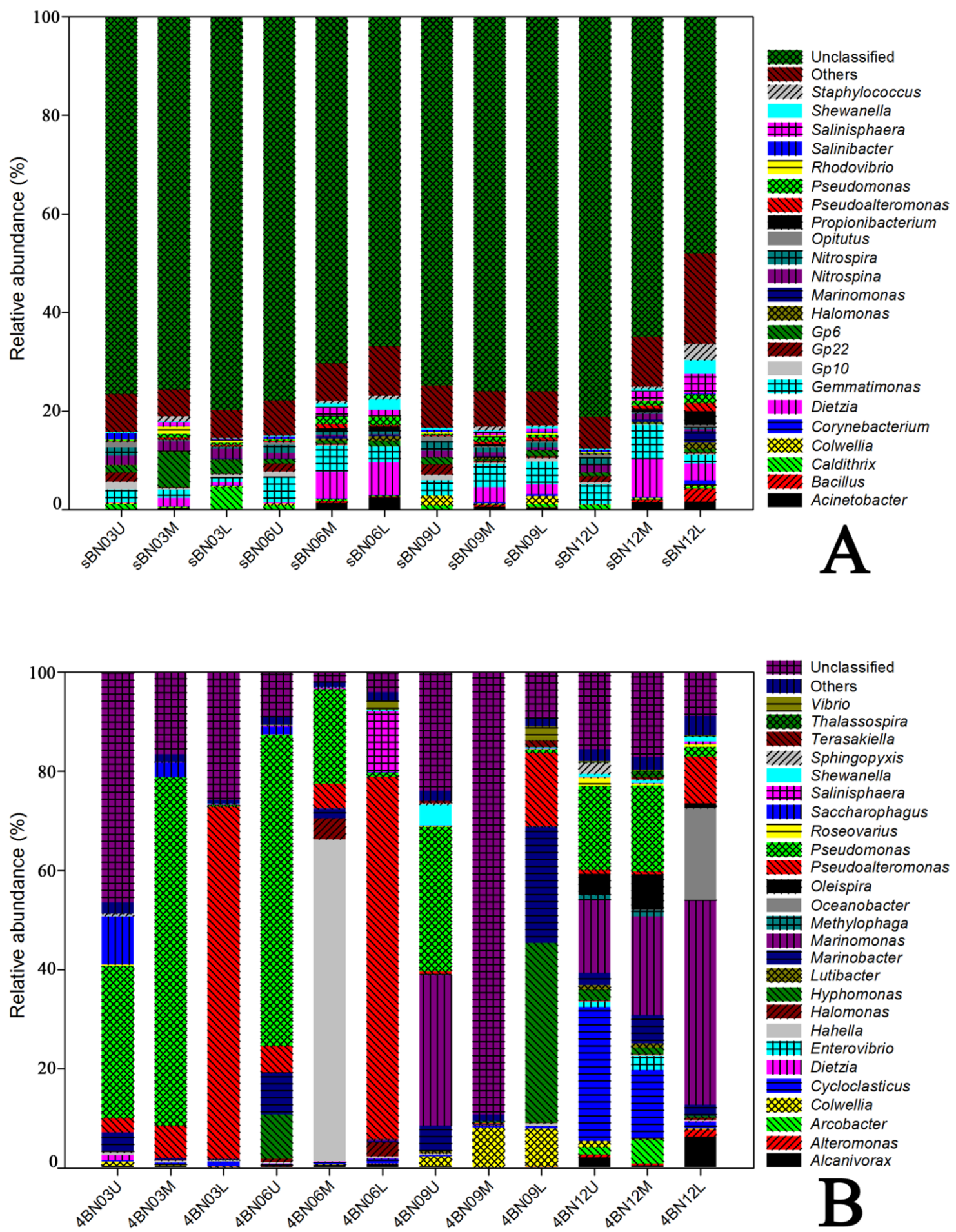

Figure 3. Relative abundances of bacteria (genus level) in the sediments and enriched consortia from the Arctic Ocean. (a) Sediment, (b) $4{ }^{\circ} \mathrm{C}$ consortia, (c) $15^{\circ} \mathrm{C}$ consortia and (d) $25^{\circ} \mathrm{C}$ consortia. The genera with abundance of more than $1 \%$ of the total tags in at least one consortium are listed in each plot. "Others" refers to the genera constituting less than $1 \%$ of the total tags of a sample for all samples. 

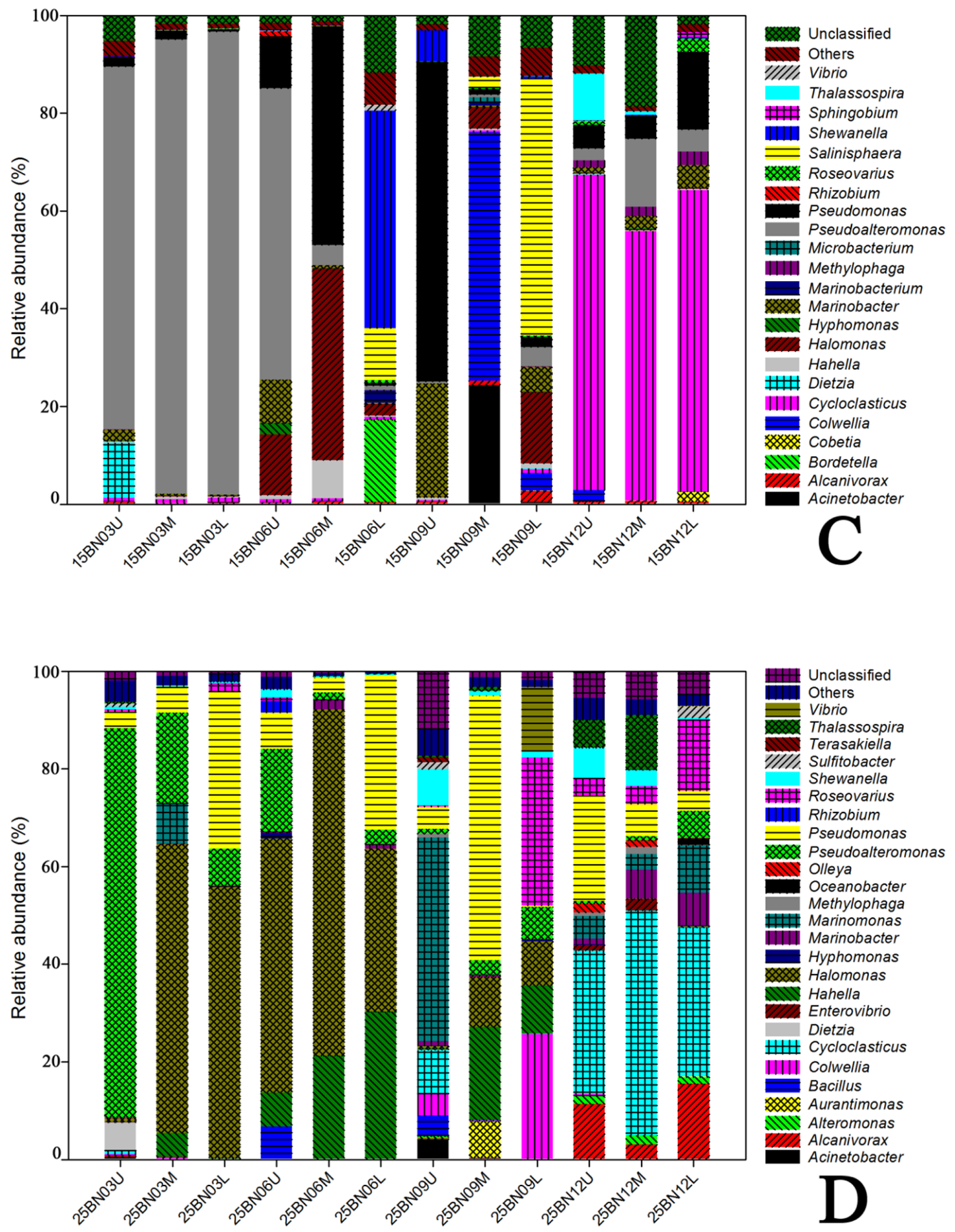

Figure 3. Continued. 


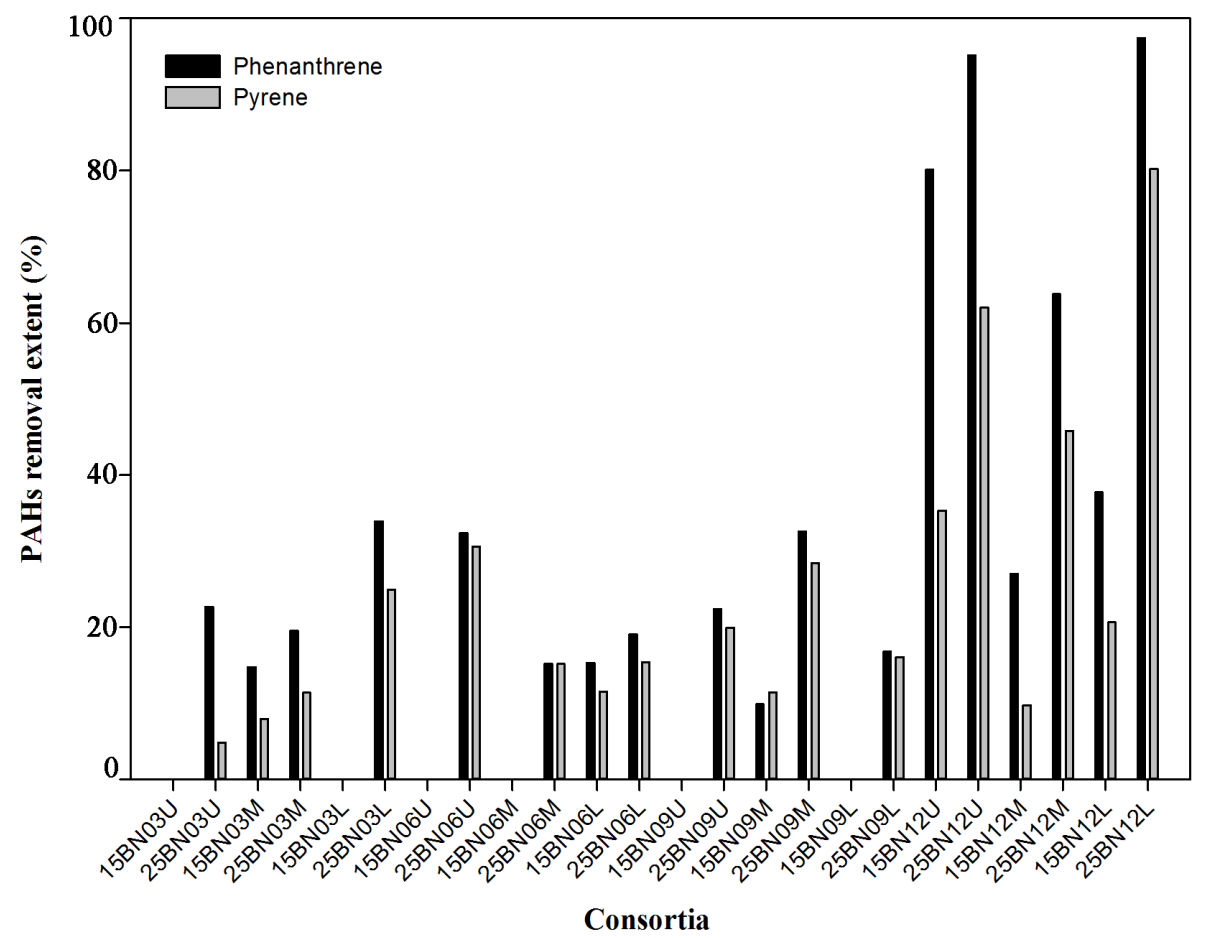

Figure 4. PAH-removal extent of the consortia that were enriched from the sediments of the Arctic Ocean. The consortia were grown with a mixture of PAHs (naphthalene, phenanthrene and pyrene) as the sole carbon and energy source. PAHs were quantified using GC-MS after pretreatments. Naphthalene was not included due to an error caused by its high volatility. Consortia names with prefixes " 15 " or " 25 " indicate that they were enriched at 15 or $25^{\circ} \mathrm{C}$, respectively.

removal extents of the consortia after 45 days of incubation at 15 and $25^{\circ} \mathrm{C}$ were calculated based on the PAH concentrations determined by GC-MS. In general, the removal extents of phenanthrene and pyrene at $25^{\circ} \mathrm{C}$ were higher than those at $15^{\circ} \mathrm{C}$ (Fig. 4). Notably, the consortia of the northernmost site (BN12) generally displayed relatively high removal extents at 15 and $25^{\circ} \mathrm{C}$. In contrast, the removal extents of the consortia from sites BN03, BN06 and BN09 were relatively low.

\subsection{Community structures of the consortia enriched with PAHs}

Thirty-six enrichment cultures corresponding to the in situ sediments were also analyzed using Illumina highthroughput sequencing (Table S3). Nearly all of the dominant bacteria in these consortia were previously described as hydrocarbon degraders. For the $4{ }^{\circ} \mathrm{C}$ treatments enriched with crude-oil-containing PAHs, the predominant bacteria included Pseudomonas, Pseudoalteromonas, Marinomonas, Hahella, Marinobacter, Hyphomonas, Cycloclasticus, Colwellia, Halomonas, Oceanobacter, Salinisphaera, Oleispira, Alteromonas and Alcanivorax (Fig. 3b, Table S5). In the treatments that were enriched with PAHs at 15 and $25^{\circ} \mathrm{C}$, Pseudoalteromonas, Cycloclasticus, Pseudomonas and Halomonas were selected as the most abundant bacte- ria. In the $15^{\circ} \mathrm{C}$ consortia (Fig. 3c), Pseudoalteromonas was the most abundant bacteria in the consortia of site BN03 and from the upper layer of BN06. In contrast, Cycloclasticus dominated the three consortia of site BN12 (55.1-64.5\%), whereas Pseudomonas was clearly dominant in the consortia of the middle layer of site BN06 and upper layer of site BN09, and was relatively dominant in all three consortia from site BN12 (Fig. 3c, Table S5).

Halomonas was the most dominant bacterium in the $25^{\circ} \mathrm{C}$ consortia (Fig. 3d), occupying 33.4-71.0\% of the tags of the communities from sites BN03 and BN06, with the exception of the upper layer of BN03. Pseudomonas was dominant in the consortia of the middle layer of site BN09 (named $25 \mathrm{BN} 09 \mathrm{M}, 54.1 \%$ of all tags), the lower layer of BN03 (25BN03L, 32.3\%), the lower layer of BN06 (25BN06L, $31.6 \%)$ and the upper layer of BN12 (25BN12U, 21.6\%). Similar to the $15^{\circ} \mathrm{C}$ consortia, Cycloclasticus dominated the northernmost consortia at $25^{\circ} \mathrm{C}$, such as the middlelayer consortium 25BN12M (46.0\%), the lower-layer consortium 25BN12L (30.5\%) and the upper-layer consortium 25BN12U (29.3\%). Additionally, they were also relatively abundant in the consortium of the upper layer of the BN09 site (25BN09U, $9.1 \%)$. 


\subsection{Bacterial diversity comparisons based on IHTS data statistical analysis and environmental parameters}

To compare the diversity indices, the tags were normalized to 7047 (the lowest tag number of the samples), and the observed OTUs, Chao1 and Shannon indices were obtained using the software package QIIME (Table S3). Overall, all of the diversity indices indicated that the sediments had the highest bacterial richness and evenness (Fig. S2AC). Among the enriched cultures, the bacterial diversity was increased with rising temperatures (Fig. S2A-B). The Chaol values of the $25^{\circ} \mathrm{C}$-enriched cultures were significantly higher compared to the other cultures $(P<0.01)$; correspondingly, the observed OTU numbers of the $25^{\circ} \mathrm{C}$ enriched cultures were also significantly higher than the $4{ }^{\circ} \mathrm{C}$ treatments $(P=0.029)$. Principal coordinate analysis (PCoA) showed that the communities of the in situ sediments and all enriched cultures could be separated using the abundant OTU data set (Fig. S2D), indicating that they had significantly different bacterial community structures; this finding was supported by the results of the nonparametric statistical Adonis method $\left(R^{2}=0.28, P=0.001\right)$. Additionally, the Mantel test results showed no correlations between the community structures of the four types of samples and the individual or total PAH concentrations of the in situ sediments.

\subsection{Community composition revealed by PCR-DGGE}

To reconfirm the bacterial composition, the PAH-degrading consortia were subjected to PCR-DGGE analysis in parallel. Figure 5 presents the DGGE profiles of 12 consortia that were enriched with PAHs at $25^{\circ} \mathrm{C}$. The bacteria, represented by bands, are listed in Supplement Table S6, and some are noted in the pattern profiles. In general, the community structures corresponded well to the IHTS results, even though the two methods targeted different regions of the $16 \mathrm{~S}$ gene. In these consortia, the three genera Cycloclasticus, Pseudomonas and Halomonas alternatively dominated the communities. Specifically, Cycloclasticus dominated all three consortia from site BN12 and the consortium (25BN09U) from the upper layer of site BN09; interestingly, it was accompanied by Alcanivorax (Fig. 5, lanes 7 and 10-12). This finding is in agreement with the results of the IHTS data (Fig. 3d). Pseudomonas dominated or shared dominance with Cycloclasticus or Halomonas in four consortia (Fig. 5, lanes 3, 6, 8 and 10) that were derived from each layer of the four sites, whereas they were relatively less abundant in three consortia (Fig. 5, lanes 2, 4 and 11) that were generated from three sites. Halomonas appeared as very strong bands in five consortia (Fig. 5, lanes 2-6) from sites BN03 and BN06. Pseudoalteromonas mainly dominated in four consortia (Fig. 5, lanes 1, 3, 5 and 6) from sites BN03 and BN06. Other bacteria, such as Marinobacter, Alcanivorax, Marinobacterium, Colwellia, Thalassospira, Celeribac-
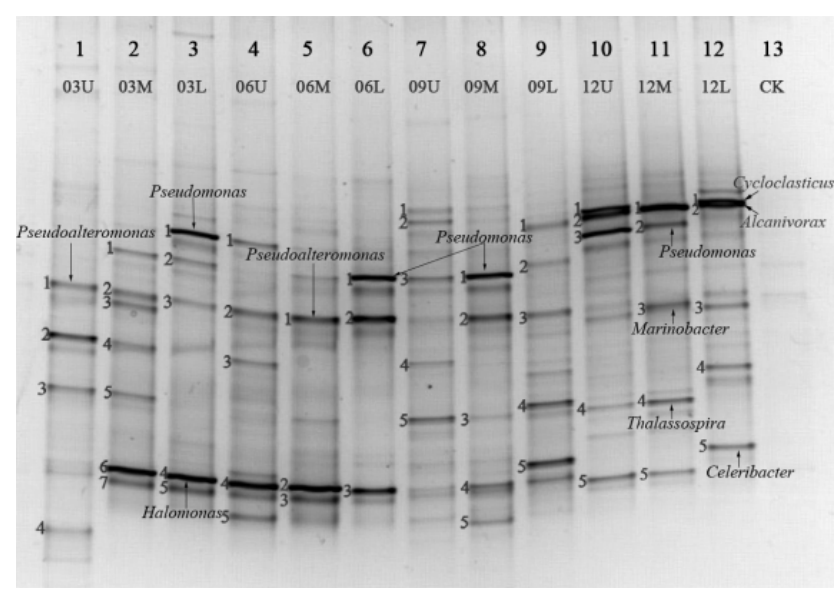

Figure 5. PCR-DGGE profiles of $12 \mathrm{PAH}$-degrading consortia that were enriched at $25^{\circ} \mathrm{C}$. Lanes 1-3, site BN03; lanes 4-6, site BN06; lanes 7-9, site BN09; lanes 10-12, BN12; and lane 13, negative control.

ter and Vibrio, were occasionally found to be strongly or weakly scattered in some of the consortia.

At low temperatures, the PAH-degrading communities varied to some extent in comparison to the $25^{\circ} \mathrm{C}$ consortia. For example, in the three consortia derived from site BN12, bacteria such as Cycloclasticus and Thalassolituus became the dominant members at $4{ }^{\circ} \mathrm{C}$ (Fig. 6a, lanes 11-13), while bacteria such as Pseudomonas, Maritalea and Thalassospira were only dominant members in $4 \mathrm{BN} 12 \mathrm{U}$ and $4 \mathrm{BN} 12 \mathrm{M}$ (Fig. 6a, lanes 11-12). In contrast, the most dominant member was the bacteria of Cycloclasticus at $15^{\circ} \mathrm{C}$ (Fig. 6b, lane 11-13), which was consistent with the composition pattern revealed in Fig. 3c.

\subsection{Bacterial isolation and their potential in PAH degradation}

Bacteria were isolated from all of the PAH-degrading consortia enriched at $15^{\circ} \mathrm{C}$ using the ONR7a medium plates whose lids were supplied with naphthalene crystals as the sole carbon source. Forty isolates were obtained that were affiliated with 12 genera of $\gamma$ - and $\alpha$-Proteobacteria and Actinobacteria (Fig. S3). Bacteria belonging to $\gamma$-Proteobacteria were the predominant isolates, including Pseudoalteromonas (18 isolates), Halomonas (6 isolates), Cycloclasticus (3 isolates), Pseudomonas (3 isolates), Marinobacter (2 isolates) and Shewanella (2 isolates). The PAH utilization test showed that only the bacteria of Cycloclasticus and Pseudomonas showed obvious growth after 2 weeks in ONR7a liquid medium supplemented with naphthalene at $15^{\circ} \mathrm{C}$.

Both the IHTS and PCR-DGGE results demonstrated that Cycloclasticus was predominant in the PAH-degrading consortia of site BN12 (Figs. 3, 5 and 6). From these consortia, three strains were isolated and named after the consortium: 15BN12U-14 (simplified as U-14), 15BN12L- 

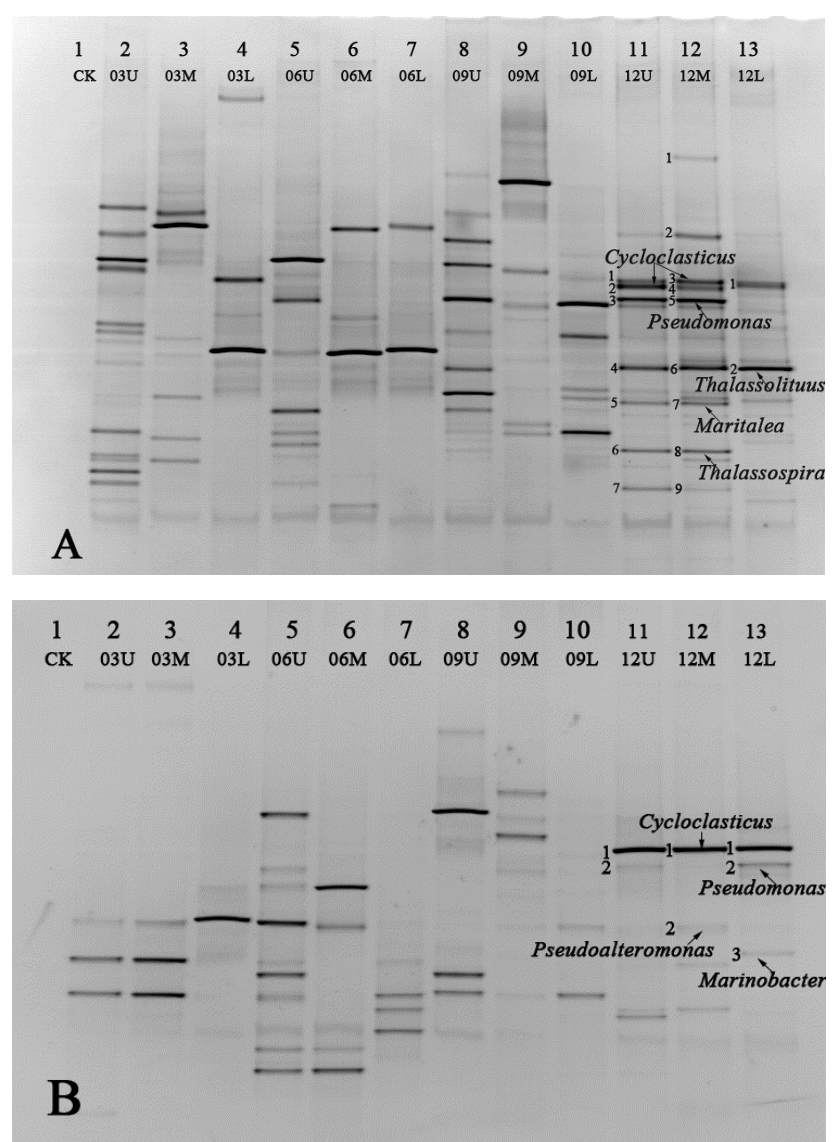

Figure 6. PCR-DGGE profiles of PAH-degrading consortia that were enriched at low temperatures. Lane CK, negative control; (a) consortia enriched at $4{ }^{\circ} \mathrm{C}$; and (b) consortia enriched at $15^{\circ} \mathrm{C}$.

10 (L-10) and 15BN12L-11 (L-11). These organisms had identical 16S rRNA gene sequences (1497 bp) and shared $99.92 \%$ sequence similarity with the $C$. pugetii $\mathrm{PS}-1^{T}$ type strain. However, they varied in morphology (Fig. S4) and genome fingerprint patterns determined by Rep-PCR (Fig. S5). Strains L-10 and L-11 resembled each other in morphology and Rep-PCR profiles; therefore, only strain L10 was chosen for further analyses. Growth tests were conducted at $15^{\circ} \mathrm{C}$ with a single PAH as the sole carbon source in ONR7a liquid medium. The results showed that strains L10 and U-14 could assimilate naphthalene and phenanthrene, but neither could utilize pyrene (Fig. 7). Moreover, strain U14 exhibited better growth than strain L-10 when utilizing phenanthrene (Fig. 7a vs. 7b).

\section{Discussion}

This report examined PAHs and PAH-degrading bacteria in the deep-sea sediments across the Arctic Ocean. Based on the data available to date, the total PAH concentrations decreased moving north toward the pole and generally decreased with sediment depth. Phenanthrene (0.64-14.61 ng g $\left.{ }^{-1}\right)$ was the most dominant among the 16 targeted EPA-priority PAHs. Based on the bacterial diversity data obtained using both culture-dependent and independent methods, the general features of PAH-degrading bacteria were revealed in the sediment samples. To the best of our knowledge, this report is the first to consider the diversity and abundance of PAH-utilizing bacteria in the deep-sea sediments of the high-latitude Arctic Ocean.

Recently, Yunker et al. (2011) examined the distribution of PAHs, plant odd alkanes, hopanes and steranes in the sediments based on a large data set to trace the origin of organic matter in the deep-sea sediments of the Arctic Ocean. They found that the central Arctic Ocean basins were compositionally distinct from the rivers and shelves. Moreover, PAH concentrations decreased from $100-755 \mathrm{ng} \mathrm{g}^{-1} \mathrm{dw}$ in the coastal sea to $35 \mathrm{ng} \mathrm{g}^{-1} \mathrm{dw}$ in the central basin (Yunker et al., 2011). Our results in this report show that the PAH concentrations are generally in agreement with this tendency (Fig. 2, Table S2). According to the theory of global distillation, it would be easier to transfer naphthalene than other PAHs of high molecular weight (HMW) over long distances (Goldberg, 1975; Friedman and Selin, 2012); however, the concentration of naphthalene was less than that of phenanthrene. This discrepancy might be partially due to its higher bioavailability and degradability. In contrast, HMW PAHs with four or more rings accumulated in larger concentrations in areas near the south of the continent, as described above (Fig. 2). Additionally, the establishment of PAH compositions can likely be attributed to bacterial mineralization. To investigate the relationship between PAH composition and bacterial communities, we analyzed the correlations between the community structures and the concentrations of individual or total PAHs using the Mantel test method. However, no definite correlation was observed. Bacterial communities in situ may be influenced by many other factors, such as nutrients and other carbon sources, in addition to the PAHs in the tested samples from the Arctic Ocean.

Various bacteria involved in PAH-degradation were identified in all of the sediments, including Cycloclasticus, Pseudomonas, Halomonas, Pseudoalteromonas, Marinomonas, Bacillus, Dietzia, Colwellia, Acinetobacter, Alcanivorax, Salinisphaera and Shewanella. However, most of these bacteria occupied less than $0.5 \%$ of the total tags (Fig. S6). After PAH enrichment, Pseudomonas, Pseudoalteromonas, Cycloclasticus, Halomonas and Marinomonas became the dominant members in the enriched cultures (Fig. S6). For example, when enriched at $4{ }^{\circ} \mathrm{C}$ with PAHs dissolved in crude oil, Pseudomonas, Pseudoalteromonas, Marinomonas, $\mathrm{Hy}$ phomonas and Cycloclasticus were identified as the dominant members (Fig. 3b and Fig. S6). These bacteria have been previously detected as the dominant members in oilenriched consortia of the coastal seawater and sea ice from the Arctic Ocean (Deppe et al., 2005; Gerdes et al., 2005; Brakstad and Bonaunet, 2006; Giudice et al., 2010). These 
findings are in contrast to those from the deep-sea oil plume that occurred during the Deepwater Horizon oil spill, which was dominated by bacteria of the order Oceanospirillales and the genus Colwellia (Hazen et al., 2010; Baelum et al., 2012). When enriched with PAHs as a sole carbon and energy source at 15 and $25^{\circ} \mathrm{C}$, the obtained PAH-degrading consortia were alternately dominated by Pseudomonas, Pseudoalteromonas, Halomonas and Cycloclasticus. A big difference in the community structures occurred between cultures grown at 4 and $15^{\circ} \mathrm{C}$ (Fig. 3 and Fig. S2), while the bacterial community structures grown at $25^{\circ} \mathrm{C}$ also varied to some extent in comparison with those grown at $15^{\circ} \mathrm{C}$, the dominant bacteria, including Cycloclasticus, Pseudomonas, Pseudoalteromonas and Halomonas, remained predominant (Fig. 3). The alpha and beta diversity indices (Fig. S2) both confirmed that significant differences existed among the consortia enriched under different temperatures, and they also indicated that temperature substantially influenced the bacterial community structure. This could be explained by the enhancement of PAH availability and the metabolic activity of the bacteria at high temperatures.

Bacteria of the genus Cycloclasticus have been recognized as obligate marine PAH degraders (Dyksterhouse et al., 1995; Yakimov et al., 2007). They usually represent one of the most predominant genera detected in crude-oil-polluted sediments or seawater (Kasai et al., 2002; Maruyama et al., 2003; McKew et al., 2007a, b; Coulon et al., 2007; Kappell et al., 2014; Dubinsky et al., 2013). In addition to coastal environments, they have also been found in the deep-sea sediments of both the Atlantic and Pacific oceans, as described in our previous reports based on culture enrichment (Cui et al., 2008; Shao et al., 2010; Wang et al., 2008). This report is the first to use IHTS to confirm the wide distribution of $C y$ cloclasticus bacteria in deep-sea sediments. In Arctic deepsea sediments, bacteria of this genus occupied $0.2-0.5 \%$ of the total bacteria sequenced in each sediment sample in situ based on the detection of sequence tags on the 16S rRNA gene. Therefore, it seems likely that they play an important role in PAH mineralization in this environment. Interestingly, the abundance of Cycloclasticus increased with sediment depth and movement from the southern to northern sites (Table S4); this finding is in contrast to PAH concentrations that decreased with depth and movement from the south to the north. This finding is most likely due to the fact that the labile carbon sources are relatively abundant in the surface sediments and are reduced in the older sediments (deep layers) and remote areas such as BN12, which is close to the North Pole. In the sediments where labile carbon sources are scarce, the PAHs may represent a key factor in the selection of PAH-degrading bacteria that adapt to the oligotrophic circumstances.

Cycloclasticus bacteria were found in all 12 of the in situ sediment samples but were difficult to cultivate on a plate, even when a simple carbon source, such as acetate and pyruvate, was used. After many attempts, three strains were fi- nally obtained on the ONR7a medium plates supplied with naphthalene crystals on the lids, showing tiny colonies after 3 weeks of incubation at $15^{\circ} \mathrm{C}$. Growth tests indicated that these Cycloclasticus strains could use naphthalene or phenanthrene as a sole carbon source but failed to utilize pyrene. In the previous study, we isolated a pyrene-degrading bacterium from a Pacific deep-sea sediment that represented the only strain of Cycloclasticus reported to date that is capable of using pyrene as its sole carbon and energy source (Wang et al., 2008); in contrast, other strains can utilize pyrene only in the presence of other PAHs, such as phenanthrene (Geiselbrecht et al., 1998).

In addition to Cycloclasticus, the following PAHdegrading bacteria, which were previously described to reside in coastal environments, were also found as dominant members in some PAH-degrading consortia in this report (in the Supplement Table S5): Pseudomonas (Niepceron et al., 2010), Marinomonas (Melcher et al., 2002), Pseudoalteromonas (Hedlund and Staley, 2006), Halomonas (Garcia et al., 2005), Alteromonas (Jin et al., 2012), Marinobacter (Hedlund et al., 2001), Vibrio (Hedlund and Staley, 2001) and Thalassospira (Kodama et al., 2008). In fact, we also isolated 64 strains from the consortia enriched at $25^{\circ} \mathrm{C}$ using M2 media plates (Wang et al., 2008), which contain more distinct carbon compounds than ONR7a media plates (i.e., sodium acetate, glucose, sucrose, sodium citrate and malic acid). Among them, only three strains (Marinomonas sp. D104, Sphingobium sp. C100 and Pseudomonas sp. C39) showed a good PAH-degradation capability at 15 and $25^{\circ} \mathrm{C}$. Genome sequencing revealed that strains D104 and C100 possessed several genes involved in the initial hydroxylation and intermediate metabolic steps of PAHs (Dong et al., 2014b, a). Particularly, strain Marinomonas sp. D104 could even degrade the PAH mixture of naphthalene, phenanthrene and pyrene at $4^{\circ} \mathrm{C}$ (unpublished data). Although Pseudoalteromonas and Halomonas were the most predominant members in many consortia (Fig. 3 and Fig. 5), in this study they failed to grow in the presence of the tested PAHs.

Pseudomonas is a common PAH-degrader in cold environments, and is frequently found in Arctic and Antarctic soils (Whyte et al., 1997; Sorensen et al., 2010; Eriksson et al., 2003; Ma et al., 2006). In this study, Pseudomonas occurred in situ as one of the most dominant bacteria and occupied $1.5-1.8 \%$ of the total bacteria sequenced from the three samples (Table S4 and Fig. 3a). In many cultures enriched with PAHs, Pseudomonas was the dominant member and even occupied up to $70 \%$ of the total populations in the $4 \mathrm{BN} 03 \mathrm{M}$ consortium (Table S5 and Fig. 3b). Coincidently, three Pseudomonas strains were obtained from the $15^{\circ} \mathrm{C}$ enrichments (Fig. S3) and were able to grow with naphthalene. However, to the best of our knowledge, Pseudomonas is less abundant in oceanic sediments (Cui et al., 2008; Wang et al., 2008; Shao et al., 2010).

In addition to the bacteria mentioned above, many other bacteria belonging to Dietzia, Alcanivorax, Colwellia, Tha- 

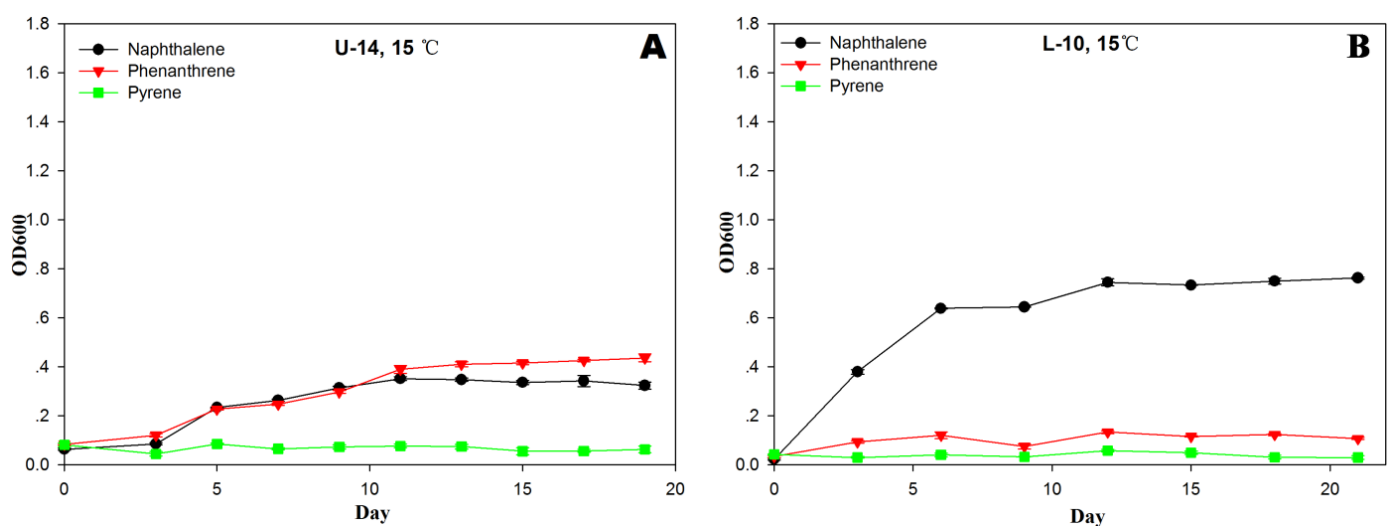

Figure 7. Growth curves of strains 15BN12U-14 and 15BN12L-10 using individual PAHs as the sole carbon and energy source in ONR7a medium. (a, b) Strain U-14 and L-10 cultivated at $15^{\circ}$ C, respectively. $\mathrm{OD}_{600}$ denotes optical density at $600 \mathrm{~nm}$.

lassolituus, Oceanobacter, Hahella and Roseovarius were also relatively dominant in some of the PAH-degrading communities. Dietzia (Alonso-Gutierrez et al., 2011), Alcanivorax (Schneiker et al., 2006), Colwellia (Baelum et al., 2012), Thalassolituus (Yakimov et al., 2004) and Oceanobacter (Teramoto et al., 2009) have been reported as hydrocarbondegrading bacteria, but not as PAH degraders. It is noteworthy that bacteria of Dietzia were abundant in situ, particularly in the middle or lower layers of all sediments, and occupied $1.65-7.8 \%$ of the total tags (Fig. 3a, Table S4). These organisms might thrive on alkanes in these environments, but they are not likely to thrive on PAHs because they only occupied $11.25 \%$ of the total tags in one consortium (the upper layer of site BN03, enriched at $15^{\circ} \mathrm{C}$ ) (Fig. 3c, Table S5). Interestingly, bacteria of Thalassolituus occurred as rare species (abundance $<0.01 \%$ ) in all in situ sediments. They became predominant in the $4^{\circ} \mathrm{C}$ cultures of site BN12 enriched with oil containing PAHs (Fig. 6a), but were diluted from the PAH-enriched cultures at both 15 and $25^{\circ} \mathrm{C}$ (Fig. $6 \mathrm{~b}$ and Fig. 5). These results were quite consistent with their aliphatic hydrocarbon-degrading and psychrotolerant characteristics (Yakimov et al., 2004).

It is worth mentioning that the once frequently reported PAH-degrading bacteria Novosphingobium spp. were not detected in the sediments of the Arctic Ocean. These bacteria are common PAH degraders in both marine and terrestrial environments (Gan et al., 2013). In our previous reports, they occurred as a predominant PAH degrader in nearly all PAH enrichment cultures, such as those from the deep-sea column of the Indian Ocean (Yuan et al., 2009) and those from hydrothermal sediments of the Lau Basin (Dong et al., 2011). Other reports also proved the widespread distribution of Novosphingobium bacteria and confirmed their roles as effective PAH degraders (Balkwill et al., 1997; Sohn et al., 2004; Yuan et al., 2009; Notomista et al., 2011). Similar to Novosphingobium, bacteria of Sphingomonas and Neptunomonas were not found in the sediments of the Arctic
Ocean, although they are also common PAH degraders in marine environments (Demaneche et al., 2004; Hedlund et al., 1999).

In summary, various PAHs and degrading bacteria are ubiquitous in the Arctic deep-sea sediments. In general, the total PAH concentrations decreased with sediment depths and movement from the south to the north, and ranged from 2.0 to $41.6 \mathrm{ng} \mathrm{g}^{-1} \mathrm{dw}$. Correspondingly, various bacteria involved in PAH degradation existed in the deepsea sediments, including the obligate marine hydrocarbondegrading bacteria Cycloclasticus, Alcanivorax and Thalassolituus, as well as Pseudomonas, Pseudoalteromonas, Marinobacter, Marinomonas, Acinetobacter, Bacillus, Colwellia, Dietzia, Halomonas, Rhodovibrio, Salinisphaera and Shewanella. Among them, Cycloclasticus, Pseudomonas, Pseudoalteromonas, Marinomonas, Halomonas and Dietzia may play a more important role in PAH degradation in situ in the Arctic Ocean. Bioattenuation of PAHs occurs while bacteria survive in the remote deep-sea areas, which are cold, dark, oligotrophic, high pressure and perennially covered in ice.

\section{The Supplement related to this article is available online at doi:10.5194/bg-12-2163-2015-supplement.}

Author contributions. Z. Z. Shao and C. M. Dong designed research; X. H. Bai and C. M. Dong performed research; C. M. Dong, Z. Z. Shao, X. H. Bai, H. F. Sheng, L. P. Jiao and H. W. Zhou analyzed data; and C. M. Dong and Z. Z. Shao contributed to the writing of the paper.

Acknowledgements. The authors greatly thank the whole team of the fourth Arctic Research Expedition of the Xuelong icebreaker and the Chinese Arctic and Antarctic Administration. This work 
was financially supported by the National Natural Science Foundation of China (41206158, 41076105), the High-Tech Research and Development Program of China (2012AA092102), the China Polar Environment Investigation and Estimate Project (2012-2015) and the Public Welfare Project of SOA (201005032).

Edited by: G. Herndl

\section{References}

Alonso-Gutierrez, J., Teramoto, M., Yamazoe, A., Harayama, S., Figueras, A., and Novoa, B.: Alkane-degrading properties of Dietzia sp. H0B, a key player in the Prestige oil spill biodegradation (NW Spain), J. Appl. Microbiol., 111, 800-810, doi:10.1111/j.1365-2672.2011.05104.x, 2011.

Baelum, J., Borglin, S., Chakraborty, R., Fortney, J. L., Lamendella, R., Mason, O. U., Auer, M., Zemla, M., Bill, M., Conrad, M. E., Malfatti, S. A., Tringe, S. G., Holman, H. Y., Hazen, T. C., and Jansson, J. K.: Deep-sea bacteria enriched by oil and dispersant from the Deepwater Horizon spill, Environ. Microbiol., 14, 2405-2416, doi:10.1111/j.1462-2920.2012.02780.x, 2012.

Balkwill, D. L., Drake, G. R., Reeves, R. H., Fredrickson, J. K., White, D. C., Ringelberg, D. B., Chandler, D. P., Romine, M. F., Kennedy, D. W., and Spadoni, C. M.: Taxonomic study of aromatic-degrading bacteria from deep-terrestrial-subsurface sediments and description of Sphingomonas aromaticivorans sp. nov., Sphingomonas subterranea sp. nov., and Sphingomonas stygia sp. nov, Int. J. Syst. Bacteriol., 47, 191-201, 1997.

Baumard, P., Budzinski, H., and Garrigues, P.: Polycyclic aromatic hydrocarbons in sediments and mussels of the western Mediterranean sea, Environ. Toxicol. Chem., 17, 765-776, doi:10.1002/etc.5620170501, 1998.

Becker, S., Halsall, C. J., Tych, W., Hung, H., Attewell, S., Blanchard, P., Li, H., Fellin, P., Stern, G., Billeck, B., and Friesen, S.: Resolving the Long-Term Trends of Polycyclic Aromatic Hydrocarbons in the Canadian Arctic Atmosphere, Environ. Sci. Tech. Lib., 40, 3217-3222, doi:10.1021/es0523461, 2006.

Benner, R., Benitez-Nelson, B., Kaiser, K., and Amon, R. M. W.: Export of young terrigenous dissolved organic carbon from rivers to the Arctic Ocean, Geophys. Res. Lett., 31, L05305, doi:10.1029/2003GL019251, 2004.

Boeuf, D., Humily, F., and Jeanthon, C.: Diversity of Arctic pelagic Bacteria with an emphasis on photoheterotrophs: a review, Biogeosciences, 11, 3309-3322, doi:10.5194/bg-11-33092014, 2014.

Brakstad, O. G. and Bonaunet, K.: Biodegradation of petroleum hydrocarbons in seawater at low temperatures $\left(0-5^{\circ} \mathrm{C}\right)$ and bacterial communities associated with degradation, Biodegradation, 17, 71-82, doi:10.1007/s10532-005-3342-8, 2006.

Coulon, F., McKew, B. A., Osborn, A. M., McGenity, T. J., and Timmis, K. N.: Effects of temperature and biostimulation on oil-degrading microbial communities in temperate estuarine waters, Environ. Microbiol., 9, 177-186, doi:10.1111/j.14622920.2006.01126.x, 2007.

Cui, Z., Lai, Q., Dong, C., and Shao, Z.: Biodiversity of polycyclic aromatic hydrocarbon-degrading bacteria from deep sea sediments of the Middle Atlantic Ridge, Environ. Microbiol., 10, 2138-2149, 2008.
Demaneche, S., Meyer, C., Micoud, J., Louwagie, M., Willison, J. C., and Jouanneau, Y.: Identification and functional analysis of two aromatic-ring-hydroxylating dioxygenases from a sphingomonas strain that degrades various polycyclic aromatic hydrocarbons, Appl. Environ. Microbiol., 70, 6714-6725, doi:10.1128/AEM.70.11.6714-6725.2004, 2004.

Deppe, U., Richnow, H. H., Michaelis, W., and Antranikian, G.: Degradation of crude oil by an arctic microbial consortium, Extremophiles, 9, 461-470, doi:10.1007/s00792-005-0463-2, 2005.

Dong, C., Chen, L., Liao, Y., and Shao, Z.: Phylogenetic and degrading genes analysis of a PAHdegrading bacterium TVG9-VII from deep-sea hydrythermal environment, Acta Microbiol. Sin., 51, 1548-1554, 2011.

Dong, C., Bai, X., Lai, Q., Xie, Y., Chen, X., and Shao, Z.: Draft Genome Sequence of Sphingobium sp. Strain C100, a Polycyclic Aromatic Hydrocarbon-Degrading Bacterium from the Deep-Sea Sediment of the Arctic Ocean, Genome Announc., 2, 2(1):e01210-13, doi:10.1128/genomeA.01210-13, 2014a.

Dong, C., Bai, X., Lai, Q., Xie, Y., Chen, X., and Shao, Z.: Draft Genome Sequence of Marinomonas sp. Strain D104, a Polycyclic Aromatic Hydrocarbon-Degrading Bacterium from the Deep-Sea Sediment of the Arctic Ocean, Genome Announc., 2, 2(1):e1211-13, doi:10.1128/genomeA.01211-13, 2014b.

Dubinsky, E. A., Conrad, M. E., Chakraborty, R., Bill, M., Borglin, S. E., Hollibaugh, J. T., Mason, O. U., Y., M. P., Reid, F. C., Stringfellow, W. T., Tom, L. M., Hazen, T. C., and Andersen, G. L.: Succession of hydrocarbon-degrading bacteria in the aftermath of the deepwater horizon oil spill in the gulf of Mexico, Environ. Sci. Tech. Lib., 47, 10860-10867, doi:10.1021/es401676y, 2013.

Dyksterhouse, S. E., Gray, J. P., Herwig, R. P., Lara, J. C., and Staley, J. T.: Cycloclasticus pugetii gen. nov., sp. nov., an aromatic hydrocarbon-degrading bacterium from marine sediments, Int. J. Syst. Bacteriol., 45, 116-123, 1995.

Eriksson, M., Sodersten, E., Yu, Z., Dalhammar, G., and Mohn, W. W.: Degradation of Polycyclic Aromatic Hydrocarbons at Low Temperature under Aerobic and Nitrate-Reducing Conditions in Enrichment Cultures from Northern Soils, Appl. Environ. Microbiol., 69, 275-284, 2003.

Friedman, C. L. and Selin, N. E.: Long-range atmospheric transport of polycyclic aromatic hydrocarbons: a global 3-D model analysis including evaluation of Arctic sources, Environ. Sci. Tech. Lib., 46, 9501-9510, doi:10.1021/es301904d, 2012.

Gan, H. M., Hudson, A. O., Rahman, A. Y., Chan, K. G., and Savka, M. A.: Comparative genomic analysis of six bacteria belonging to the genus Novosphingobium: insights into marine adaptation, cell-cell signaling and bioremediation, BMC Genomics, 14:431, doi:10.1186/1471-2164-14-431, 2013.

Garcia, M. T., Ventosa, A., and Mellado, E.: Catabolic versatility of aromatic compound-degrading halophilic bacteria, FEMS Microbiol. Ecol., 54, 97-109, doi:10.1016/j.femsec.2005.03.009, 2005.

Gautier, D. L., Bird, K. J., Charpentier, R. R., Grantz, A., Houseknecht, D. W., Klett, T. R., Moore, T. E., Pitman, J. K., Schenk, C. J., and Schuenemeyer, J. H.: Assessment of undiscovered oil and gas in the Arctic, Science, 324, 1175-1179, 2009.

Geiselbrecht, A. D., Hedlund, B. P., Tichi, M. A., and Staley, J. T.: Isolation of Marine Polycyclic Aromatic Hydrocarbon (PAH)Degrading Cycloclasticus Strains from the Gulf of Mexico and 
Comparison of Their PAH Degradation Ability with That of Puget Sound Cycloclasticus Strains, Appl. Environ. Microbiol., 64, 4703-4710, 1998.

Gerdes, B., Brinkmeyer, R., Dieckmann, G., and Helmke, E.: Influence of crude oil on changes of bacterial communities in Arctic sea-ice, FEMS Microbiol. Ecol., 53, 129-139, doi:10.1016/j.femsec.2004.11.010, 2005.

Giudice, A. L., Bruni, V., Domenico, M. D., and Michaud, L.: Psychrophiles - Cold-Adapted Hydrocarbon-Degrading Microorganisms, in: Handbook of Hydrocarbon and Lipid Microbiology, edited by: Timmis, K. N., Springer Berlin Heidelberg, 18971921, 2010.

Goldberg, E. D.: Synthetic organohalides in the sea, Proc. R. Soc. Lond. B. Biol. Sci., 189, 277-289, 1975.

Halsall, C. J., Barrie, L. A., Fellin, P., Muir, D. C. G., Billeck, B. N., Lockhart, L., Rovinsky, F. Y., Kononov, E. Y., and Pastukhov, B.: Spatial and Temporal Variation of Polycyclic Aromatic Hydrocarbons in the Arctic Atmosphere, Environ. Sci. Tech. Lib., 31, 3593-3599, doi:10.1021/es970342d, 1997.

Haritash, A. K. and Kaushik, C. P.: Biodegradation aspects of polycyclic aromatic hydrocarbons (PAHs): a review, J. Hazard Mater., 169, 1-15, doi:10.1016/j.jhazmat.2009.03.137, 2009.

Hazen, T. C., Dubinsky, E. A., DeSantis, T. Z., Andersen, G. L., Piceno, Y. M., Singh, N., Jansson, J. K., Probst, A., Borglin, S. E., Fortney, J. L., Stringfellow, W. T., Bill, M., Conrad, M. E., Tom, L. M., Chavarria, K. L., Alusi, T. R., Lamendella, R., Joyner, D. C., Spier, C., Baelum, J., Auer, M., Zemla, M. L., Chakraborty, R., Sonnenthal, E. L., D’Haeseleer, P., Holman, H. Y., Osman, S., Lu, Z., Van Nostrand, J. D., Deng, Y., Zhou, J., and Mason, O. U.: Deep-sea oil plume enriches indigenous oil-degrading bacteria, Science, 330, 204-208, doi:10.1126/science.1195979, 2010.

Hedlund, B. P. and Staley, J. T.: Vibrio cyclotrophicus sp. nov., a polycyclic aromatic hydrocarbon (PAH)-degrading marine bacterium, Int. J. Syst. Evol. Micr., 51, 61-66, 2001.

Hedlund, B. P. and Staley, J. T.: Isolation and characterization of Pseudoalteromonas strains with divergent polycyclic aromatic hydrocarbon catabolic properties, Environ. Microbiol. 8, 178$182,2006$.

Hedlund, B. P., Geiselbrecht, A. D., Bair, T. J., and Staley, J. T.: Polycyclic aromatic hydrocarbon degradation by a new marine bacterium, Neptunomonas naphthovorans gen. nov., sp. nov, Appl. Environ. Microbiol., 65, 251-259, 1999.

Hedlund, B. P., Geiselbrecht, A. D., and Staley, J. T.: Marinobacter strain NCE312 has a Pseudomonas-like naphthalene dioxygenase, FEMS Microbiol. Lett., 201, 47-51, doi:10.1111/j.15746968.2001.tb10731.x, 2001.

Jin, H. M., Kim, J. M., Lee, H. J., Madsen, E. L., and Jeon, C. O.: Alteromonas As a Key Agent of Polycyclic Aromatic Hydrocarbon Biodegradation in Crude Oil-Contaminated Coastal Sediment, Environ. Sci. Tech. Lib., 46, 7731-7740, doi:10.1021/es3018545, 2012.

Kappell, A. D., Wei, Y., Newton, R. J., Van Nostrand, J. D., Zhou, J., McLellan, S. L., and Hristova, K. R.: The polycyclic aromatic hydrocarbon degradation potential of Gulf of Mexico native coastal microbial communities after the Deepwater Horizon oil spill, Front. Microbiol., 5:205, doi:10.3389/fmicb.2014.00205, 2014.

Kasai, Y., Kishira, H., and Harayama, S.: Bacteria belonging to the genus cycloclasticus play a primary role in the degradation of aromatic hydrocarbons released in a marine environment, Appl. Environ. Microbiol., 68, 5625-5633, 2002.

Kodama, Y., Stiknowati, L. I., Ueki, A., Ueki, K., and Watanabe, K.: Thalassospira tepidiphila sp. nov., a polycyclic aromatic hydrocarbon-degrading bacterium isolated from seawater, Int. J. Syst. Evol. Micr., 58, 711-715, doi:10.1099/ijs.0.65476-0, 2008.

Konn, C., Charlou, J. L., Donval, J. P., Holm, N. G., Dehairs, F., and Bouillon, S.: Hydrocarbons and oxidized organic compounds in hydrothermal fluids from Rainbow and Lost City ultramafichosted vents, Chem. Geol., 258, 299-314, 2009.

Latimer, J. S. and Zheng, J.: The Sources, Transport, and Fate of PAHs in the Marine Environment, in: PAHs: An Ecotoxicological Perspective, John Wiley \& Sons, Ltd, UK, 7-33, 2003.

Lobbes, J. M., Fitznar, H. P., and Kattner, G.: Biogeochemical characteristics of dissolved and particulate organic matter in Russian rivers entering the Arctic Ocean, Geochim. Cosmochim. Ac., 64, 2973-2983, 2000.

Ma, Y., Wang, L., and Shao, Z.: Pseudomonas, the dominant polycyclic aromatic hydrocarbon-degrading bacteria isolated from Antarctic soils and the role of large plasmids in horizontal gene transfer, Environ. Microbiol., 8, 455-465, doi:10.1111/j.14622920.2005.00911.x, 2006.

Maruyama, A., Ishiwata, H., Kitamura, K., Sunamura, M., Fujita, T., Matsuo, M., and Higashihara, T.: Dynamics of microbial populations and strong selection for Cycloclasticus pugetii following the Nakhodka oil spill, Microb. Ecol., 46, 442-453, doi:10.1007/s00248-002-3010-z, 2003.

McClintock, J. B.: Arctic: sea-ice loss sparks oil drilling boom, Nature, 479, p. 478, doi:10.1038/479478e, 2011

McKew, B. A., Coulon, F., Osborn, A. M., Timmis, K. N., and McGenity, T. J.: Determining the identity and roles of oil-metabolizing marine bacteria from the Thames estuary, UK, Environ. Microbiol., 9, 165-176, doi:10.1111/j.14622920.2006.01125.x, 2007a.

McKew, B. A., Coulon, F., Yakimov, M. M., Denaro, R., Genovese, M., Smith, C. J., Osborn, A. M., Timmis, K. N., and McGenity, T. J.: Efficacy of intervention strategies for bioremediation of crude oil in marine systems and effects on indigenous hydrocarbonoclastic bacteria, Environ. Microbiol., 9, 1562-1571, doi:10.1111/j.1462-2920.2007.01277.x, 2007b.

Melcher, R. J., Apitz, S. E., and Hemmingsen, B. B.: Impact of irradiation and polycyclic aromatic hydrocarbon spiking on microbial populations in marine sediment for future aging and biodegradability studies, Appl. Environ. Microbiol., 68, 28582868, 2002.

Niepceron, M., Portet-Koltalo, F., Merlin, C., Motelay-Massei, A., Barray, S., and Bodilis, J.: Both Cycloclasticus spp. and Pseudomonas spp. as PAH-degrading bacteria in the Seine estuary (France), FEMS Microbiol Ecol, 71, 137-147, doi:10.1111/j.1574-6941.2009.00788.x, 2010.

Notomista, E., Pennacchio, F., Cafaro, V., Smaldone, G., Izzo, V., Troncone, L., Varcamonti, M., and Di Donato, A.: The marine isolate Novosphingobium sp. PP1Y shows specific adaptation to use the aromatic fraction of fuels as the sole carbon and energy source, Microb. Ecol., 61, 582-594, doi:10.1007/s00248010-9786-3, 2011.

Opsahl, S., Benner, R., and Amon, R. M. W.: Major flux of terrigenous dissolved organic matter through the Arctic Ocean, 8, 
American Society of Limnology and Oceanography, Waco, TX, ETATS-UNIS, 1999.

Ortega-Retuerta, E., Jeffrey, W. H., Babin, M., Bélanger, S., Benner, R., Marie, D., Matsuoka, A., Raimbault, P., and Joux, F.: Carbon fluxes in the Canadian Arctic: patterns and drivers of bacterial abundance, production and respiration on the Beaufort Sea margin, Biogeosciences, 9, 3679-3692, doi:10.5194/bg-9-36792012, 2012.

Proskurowski, G., Lilley, M. D., Seewald, J. S., Fruh-Green, G. L., Olson, E. J., Lupton, J. E., Sylva, S. P., and Kelley, D. S.: Abiogenic Hydrocarbon Production at Lost City Hydrothermal Field, Science, 319, 604-607, 2008.

Schmidt, C. W.: Offshore exploration to commence in the Arctic: can shell's oil-spill response plans keep up?, Environ. Health Persp., 120, 194-199, doi:10.1289/ehp.120-a194, 2012.

Schneiker, S., Martins dos Santos, V. A., Bartels, D., Bekel, T., Brecht, M., Buhrmester, J., Chernikova, T. N., Denaro, R., Ferrer, M., Gertler, C., Goesmann, A., Golyshina, O. V., Kaminski, F., Khachane, A. N., Lang, S., Linke, B., McHardy, A. C., Meyer, F., Nechitaylo, T., Puhler, A., Regenhardt, D., Rupp, O., Sabirova, J. S., Selbitschka, W., Yakimov, M. M., Timmis, K. N., Vorholter, F. J., Weidner, S., Kaiser, O., and Golyshin, P. N.: Genome sequence of the ubiquitous hydrocarbon-degrading marine bacterium Alcanivorax borkumensis, Nat. Biotechnol., 24, 997-1004, doi:10.1038/nbt1232, 2006.

Shao, Z., Cui, Z., Dong, C., Lai, Q., and Chen, L.: Analysis of a PAH-degrading bacterial population in subsurface sediments on the Mid-Atlantic Ridge, Deep-Sea Res. 57, 724-730, 2010.

Simoneit, B. R. T., Lein, A. Y., Peresypkin, V. I., and Osipov, G. A.: Composition and origin of hydrothermal petroleum and associated lipids in the sulfide deposits of the Rainbow field (MidAtlantic Ridge at 36N), Geochim. Cosmochim.a Ac., 68, 22752294, 2004.

Sohn, J. H., Kwon, K. K., Kang, J. H., Jung, H. B., and Kim, S. J.: Novosphingobium pentaromativorans sp. nov., a high-molecularmass polycyclic aromatic hydrocarbon-degrading bacterium isolated from estuarine sediment, Int. J. Syst. Evol. Micr., 54, 14831487, doi:10.1099/ijs.0.02945-0, 2004.

Sorensen, S. R., Johnsen, A. R., Jensen, A., and Jacobsen, C. S.: Presence of psychrotolerant phenanthrene-mineralizing bacterial populations in contaminated soils from the Greenland High Arctic, FMEs Microbiol. Lett., 305, 148-154, doi:10.1111/j.15746968.2010.01920.x, 2010.

Teramoto, M., Suzuki, M., Okazaki, F., Hatmanti, A., and Harayama, S.: Oceanobacter-related bacteria are important for the degradation of petroleum aliphatic hydrocarbons in the tropical marine environment, Microbiology+, 155, 3362-3370, doi:10.1099/mic.0.030411-0, 2009.
Wang, B., Lai, Q., Cui, Z., Tan, T., and Shao, Z.: A pyrenedegrading consortium from deep-sea sediment of the West Pacific and its key member Cycloclasticus sp. P1, Environ. Microbiol., 10, 1948-1963, doi:10.1111/j.1462-2920.2008.01611.x, 2008.

Whyte, L. G., Bourbonniere, L., and Greer, C. W.: Biodegradation of petroleum hydrocarbons by psychrotrophic Pseudomonas strains possessing both alkane (alk) and naphthalene (nah) catabolic pathways, Appl. Environ. Microbiol., 63, 3719-3723, 1997.

Witt, G.: Polycyclic aromatic hydrocarbons in water and sediment of the Baltic Sea, Mar. Poll. Bull., 31, 237-248, doi:10.1016/0025-326X(95)00174-L, 1995.

Wu, J. Y., Jiang, X. T., Jiang, Y. X., Lu, S. Y., Zou, F., and Zhou, H. W.: Effects of polymerase, template dilution and cycle number on PCR based 16S rRNA diversity analysis using the deep sequencing method, BMC Microbiol., 10:255, doi:10.1186/14712180-10-255, 2010.

Yakimov, M. M., Giuliano, L., Denaro, R., Crisafi, E., Chernikova, T. N., Abraham, W. R., Luensdorf, H., Timmis, K. N., and Golyshin, P. N.: Thalassolituus oleivorans gen. nov., sp. nov., a novel marine bacterium that obligately utilizes hydrocarbons, Int. J. Syst. Evol. Micr., 54, 141-148, 2004.

Yakimov, M. M., Timmis, K. N., and Golyshin, P. N.: Obligate oildegrading marine bacteria, Curr. Opin. Biotechnol., 18, 257-266, doi:10.1016/j.copbio.2007.04.006, 2007.

Yuan, J., Lai, Q., Zheng, T., and Shao, Z.: Novosphingobium indicum sp. nov., a polycyclic aromatic hydrocarbon-degrading bacterium isolated from a deep-sea environment, Int. J. Syst. Evol. Micr., 59, 2084-2088, 2009.

Yunker, M. B. and Macdonald, R. W.: Composition and Origins of Polycyclic Aromatic Hydrocarbons in the Mackenzie River and on the Beaufort Sea Shelf, Arctic, 48, 118-129, 1995.

Yunker, M. B., Macdonald, R. W., Snowdon, L. R., and Fowler, B. R.: Alkane and PAH biomarkers as tracers of terrigenous organic carbon in Arctic Ocean sediments, Org. Geochem., 42, 11091146, 2011.

Zaborska, A., Carroll, J., Pazdro, K., and Pempkowiak, J.: Spatiotemporal patterns of PAHs, PCBs and HCB in sediments of the western Barents Sea, Oceanologia, 53, 1005-1026, 2011.

Zheng, G. J., Man, B. K. W., Lam, J. C. W., Lam, M. H. W., and Lam, P. K. S.: Distribution and sources of polycyclic aromatic hydrocarbons in the sediment of a sub-tropical coastal wetland, Water Res., 36, 1457-1468, 2002. 